\title{
Synthesis and Physical Properties of Novel 7, 12-Diaryl-N-phenylbenzo[k]fluoranthene-9, 10-dicarbox- imides
}

\author{
Yuki Nakahara ${ }^{1}$, Haruki Shimosasa ${ }^{1}$, Ryuta $_{\text {Miyatake }}{ }^{2}$, Naoki Kobayashi ${ }^{1}$, Mitsunori Oda ${ }^{1}{ }^{*}$ \\ ${ }^{1}$ Department of Chemistry, Faculty of Science, Shinshu University, Matsumoto, Japan \\ ${ }^{2}$ Centre for Environmental Conservation and Research Safety, University of Toyama, Toyama, Japan
}

Email address:

mituoda@shinshu-u.ac.jp (M. Oda)

*Corresponding author

\section{To cite this article:}

Yuki Nakahara, Haruki Shimosasa, Ryuta Miyatake, Naoki Kobayashi, Mitsunori Oda. Synthesis and Physical Properties of Novel 7 , 12-Diaryl- $N$-phenylbenzo[k]fluoranthene-9, 10-dicarbox- imides. Modern Chemistry. Vol. 4, No. 6, 2016, pp. 52-58. doi: $10.11648 /$ j.mc.20160406.11

Received: December 14, 2016; Accepted: December 22, 2016; Published: January 16, 2017

\begin{abstract}
The title arene-dicarboximides 8a-8d, having a benzo[ $k]$ fluoranthene skeleton, were synthesized in two steps from $\mathrm{N}$-phenyl-1, 3-diarylisobenzofuran-5, 6-dicarboximides 4a-4d by the Diels-Alder reaction with acenaphthylene and subsequent dehydration with trifluoromethanesulfonic acid. Under photo-excitation these dicarboximides emit blue light, notably, with high quantum yields.
\end{abstract}

Keywords: Isobenzofuran-Dicarboximides, Diels-Alder Reaction, Dehydration, Triflic Acid, Fluorescence

\section{Introduction}

Arene-dicarboximides, -bis(dicarboximide)s, and poly(dicarboximide)s show interesting electrochemical, photochemical, and photophysical properties, which have attracted increased attention of a wide range of chemists and physicists due to their potential application to various electronic materials and analytical reagents. [1-10] Among them, naphthalene-dicarboximides (naphthalimides) have been most studied. In 1992, Kossanyi et al. found dual fluorescence of $N$-aryl-2, 3-naphthalimides [11] and, later, Saito et al. reported that amino acids having a 1, 8-naphthalimide chromophore show sequence-selective DNA cleavage under photo-activated conditions. [12-13] In 2010, Heagy et al. reported that some 2, 3-naphthalenimides can be used in white organic light-emitting devices and also are applicable to ratiometric DNA and protein detections. [9-10]

These findings have prompted organic chemists to develop various new synthetic methods access to dicarboximide compounds. [14-17] We recently developed an efficient annulation between arene-1, 2-dicarbaldehydes and maleimides [18-21] by improving the previously reported Haddadin's result. [22] As shown in Fig. 1, various naphthalene-, anthracene-, isobenzofuran-, and benzo$[b]$ thiophene-dicarboximides $2-5$ can be obtained in one-pot from maleimides 1 and the arene-1, 2-dicarbaldehydes in good to high yields. We also reported that isobenzofuran-dicarboximides 4 served as a diene part in Diels-Alder reaction and naphthalene-

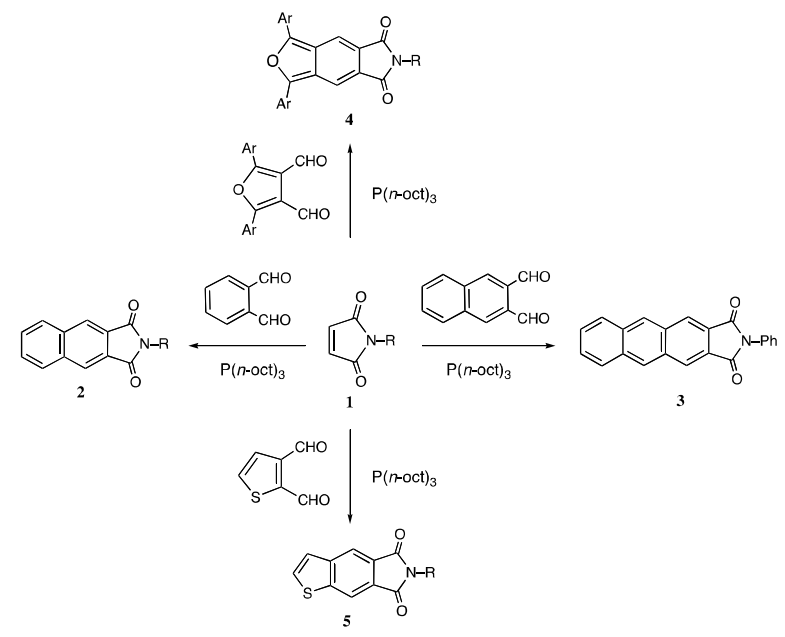

Figure 1. Various arene-dicarboximides. 


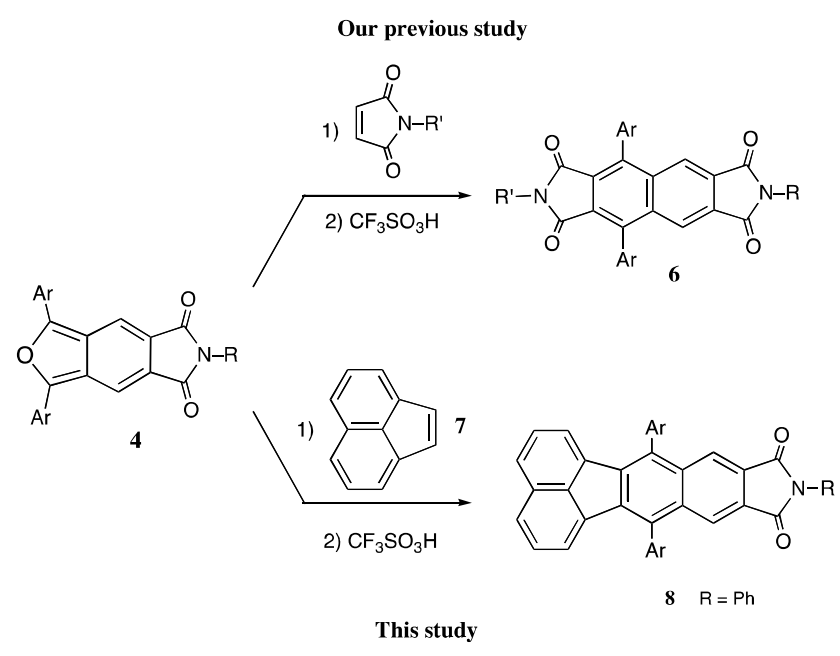

Figure 2. Diels-Alder reactions of isobenzofuran-dicarboximides 4.

Bis(dicarboximide)s 6 could be obtained by dehydration of the Diels-Alder adducts with various Brønsted acids. [19] During a course of our study on development of synthetic methods for a variety of arene-dicarboximides, we have further pursued cycloaddition reactions of 4 . In this paper, we describe transformation from $4 \mathrm{a}-4 \mathrm{~d}$ into the title compounds $8 \mathrm{a}-8 \mathrm{~d}$ by its Diels-Alder reaction with acenaphthylene (7) and subsequent dehydration with trifluoromethanesulfonic acid (triflic acid). (Fig. 2) Also, absorption and emission properties of these products are described.

\section{Results and Discussion}

In this study we employed four different 1, 3-diaryl- $N$-phenylisobenzofuran-5, 6-dicarboximides $4 \mathrm{a}-\mathrm{d}$ as a diene part in the Diels-Alder reaction. We have already reported the synthesis of $4 \mathrm{a}-\mathrm{c}$. [19] The new biphenyl-substituted derivative $4 \mathrm{~d}$ was synthesized in four steps from dimethyl 2, 5-bis (4-bromophenyl)furan-3, 4-dicarboxylate (9) according to Fig. 3. The Suzuki-Miyaura coupling of 9 with phenylboronic acid under the conditions of $\mathrm{Pd}$ (dppf) $\mathrm{Cl}_{2} / \mathrm{BINAP} / \mathrm{Cs}_{2} \mathrm{CO}_{3}$ [23] in refluxing toluene yielded biphenyl-substituted diester 10 in $77 \%$ yield. Then, this diester was transformed into $4 \mathrm{~d}$ by the previously reported three-step sequence, which involves $\mathrm{LiAlH}_{4}$ reduction, Swern oxidation [24], and phosphine-assisted annulation with $\mathrm{N}$-phenylmaleimide. The total yield of $4 \mathrm{~d}$ was $24 \%$ yield based on 10 .<smiles>COC(=O)c1c(Br)oc(Br)c1C(OC)OC</smiles>

1. $\mathrm{LiAlH}_{4} 40 \%$

2. $(\mathrm{COCl})_{2}, \mathrm{Et}_{3} \mathrm{~N}$, $90 \%$<smiles>O=Cc1c(Br)oc(Br)c1C=O</smiles>

$\mathrm{Ar}=4-\mathrm{PhC}_{6} \mathrm{H}_{4}$<smiles>O=C1C=CC(=O)N1c1ccccc1</smiles>

$68 \%$

$$
\mathrm{Ar}=4-\mathrm{BrC}_{6} \mathrm{H}_{4} \quad 9
$$<smiles>O=C1c2cc3c([Al])oc(Br)c3cc2C(=O)N1c1ccccc1</smiles>

Ar

$\mathrm{Ar}=4-\mathrm{PhC}_{6} \mathrm{H}_{4} \mathbf{4 d}$

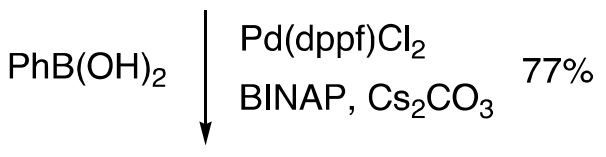

$$
\mathrm{Ar}=4-\mathrm{PhC}_{6} \mathrm{H}_{4} \quad \mathbf{1 0}
$$

Figure 3. Synthesis of 1, 3-bis (biphenyl-4-yl)-N-phenylisobenzofuran-5, 6-dicarboximide (4d).<smiles>O=C1c2cc3c([Al])oc(Br)c3cc2C(=O)N1c1ccccc1</smiles>

$\mathrm{Ar}=\mathrm{Ph}$ $4 a$

$\mathrm{Ar}=4-\mathrm{MeC}_{6} \mathrm{H}_{4} \quad$ 4b

$\mathrm{Ar}=4-\mathrm{MeOC}_{6} \mathrm{H}_{4} \quad \mathbf{4 c}$

$\mathrm{Ar}=4-\mathrm{PhC}_{6} \mathrm{H}_{4} \quad \mathbf{4 d}$

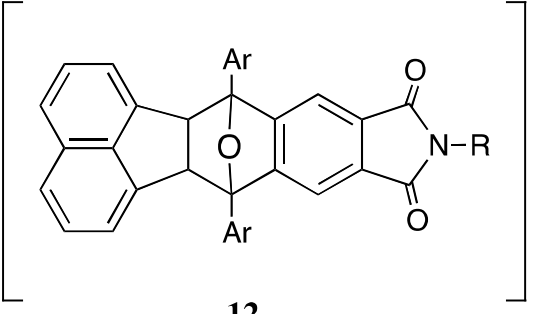

12 
Table 1. Results of the Diels-Alder reaction of 4 and dehydration reaction of 12 .

\begin{tabular}{llll}
\hline entry & Ar & $\begin{array}{l}\text { reaction conditions } \\
\text { cycloaddition//dehydration }\end{array}$ & yield/\% \\
\hline 1 & $\mathrm{C}_{6} \mathrm{H}_{5}$ & $150^{\circ} \mathrm{C} / 19 \mathrm{~h} / /$ reflux $/ 4 \mathrm{~h}$ & $42(8 \mathrm{a})$ \\
2 & $4-\mathrm{Me}-\mathrm{C}_{6} \mathrm{H}_{4}$ & $150^{\circ} \mathrm{C} / 21 \mathrm{~h} / /$ reflux $/ 4 \mathrm{~h}$ & $15(8 \mathrm{~b})$ \\
3 & $4-\mathrm{MeO}-\mathrm{C}_{6} \mathrm{H}_{4}$ & $150^{\circ} \mathrm{C} / 12 \mathrm{~h} / /$ reflux $/ 4 \mathrm{~h}$ & $34(8 \mathrm{c})$ \\
4 & $4-\mathrm{Ph}-\mathrm{C}_{6} \mathrm{H}_{4}$ & $170^{\circ} \mathrm{C} / 8 \mathrm{~h} / /$ reflux $/ 2 \mathrm{~h}$ & $34(8 \mathrm{~d})$ \\
\hline
\end{tabular}

Next, dicarboximides $4 \mathrm{a}-\mathrm{d}$ were subjected to the Diels-Alder reaction with 7 (Fig. 4). The reactions were conducted at $150-170^{\circ} \mathrm{C}$ in a sealed tube, using an excess of 7 in toluene. After removal of recovery of 7 , the crude adducts were treated with triflic acid in refluxing 1, 2-dichloroethane to give the title compounds $8 \mathrm{a}-8 \mathrm{~d}$. The reaction conditions and two-step yields are shown in Table 1. The compounds 8a$\mathrm{d}$ were obtained as orange solid and their structures were confirmed by spectroscopic analysis. Fig. 5 shows absorption and emission spectra of $8 \mathrm{a}-\mathrm{d}$ and their phtophysical properties are sammarized in Table 2.

Table 2. Photophysical properties of 8 .

\begin{tabular}{lllllll}
\hline entry & compound & $\lambda_{\max } / \mathbf{n m}$ & $\log \boldsymbol{\varepsilon}$ & $\boldsymbol{\lambda}_{\text {emi }} / \mathbf{n m}$ & Stokes shift/nm & $\boldsymbol{\Phi}$ \\
\hline 1 & $8 \mathrm{a}$ & 433 & 4.43 & 442 & 9 & 0.97 \\
2 & $8 \mathrm{~b}$ & 433 & 4.12 & 446 & 13 & 0.85 \\
3 & $8 \mathrm{c}$ & 434 & 4.50 & 443 & 9 & 0.83 \\
4 & $8 \mathrm{~d}$ & 432 & 4.44 & 444 & 12 & 0.89 \\
\hline
\end{tabular}
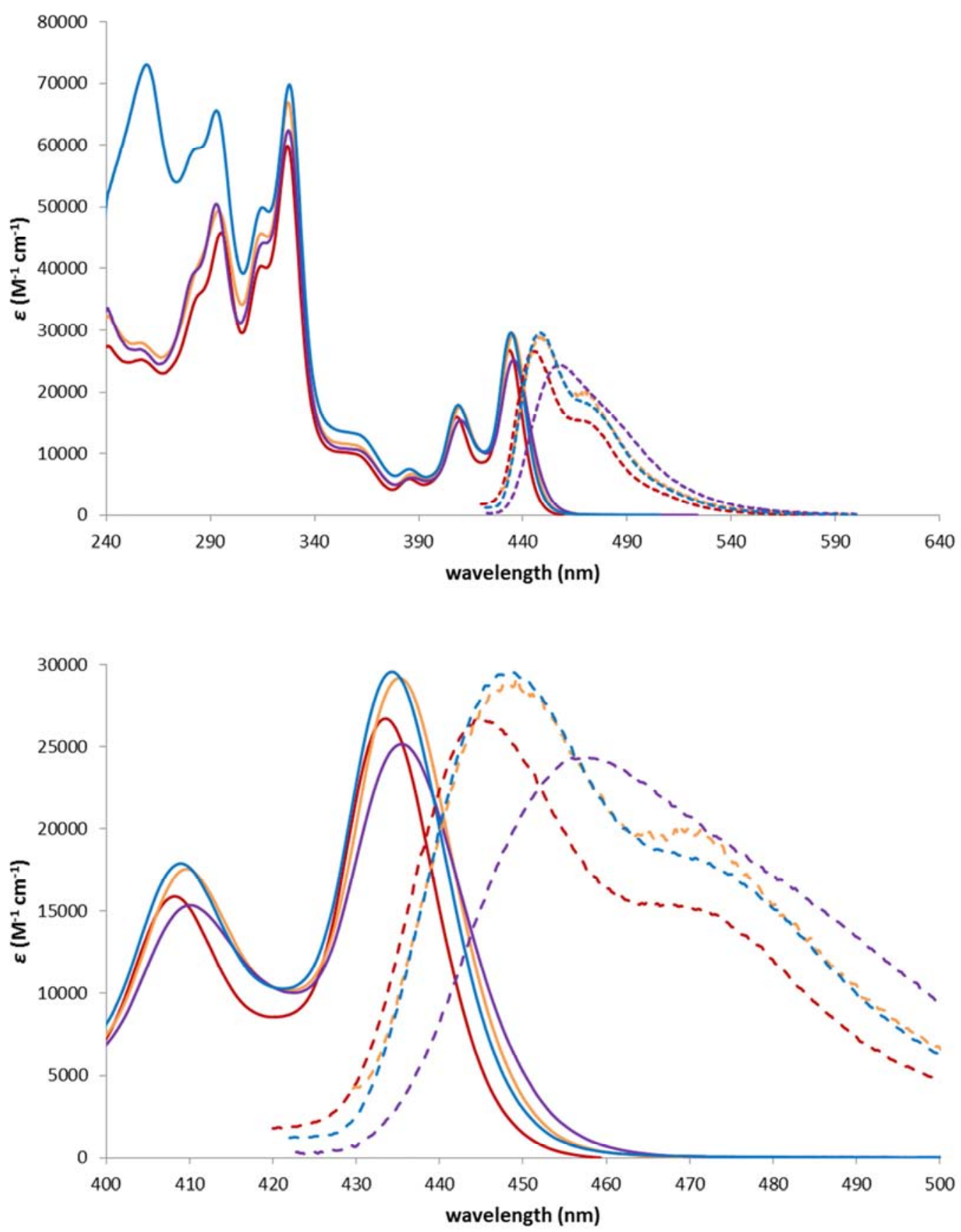


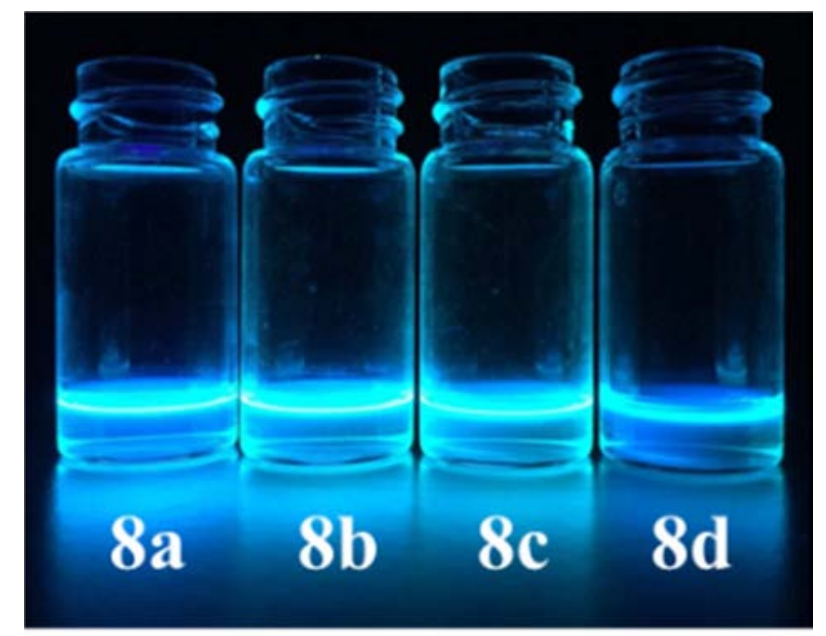

Figure 5. Top: Absorption (solid line) and normalized emission (dashed line) spectra of 8 a (red), $8 b$ (orange), $8 c$ (violet), and $8 d$ (sky blue). Middle: The expanded spectra at a range between 400 and $500 \mathrm{~nm}$. Bottom: Luminescence color of the $10^{-4} \mathrm{M}$ solutions $\left(\lambda_{e x}=365 \mathrm{~nm}\right)$ in chloroform.

Compounds $8 \mathrm{a}-8 \mathrm{c}$ show very similar absorption spectra, but the absorption coefficient increases slightly depending on electron-donating nature of the aryl substituents. The spectrum of $8 \mathrm{~d}$ was slightly different from the others, having strong absorption maxima at a range between $240-280 \mathrm{~nm}$, which are assignable to a band due to the biphenyl groups at the 7, 12 positions. The other absorption bands of $8 \mathrm{~d}$ are shown in the same way to those of $8 \mathrm{a}-8 \mathrm{c}$. Thus, the main absorptions based on the benzofluoranthene-dicarboximide skeleton show no difference between $8 \mathrm{a}-8 \mathrm{~d}$, suggesting discreteness of $\pi$-conjugation between the core skeleton and the aryl groups at the 7,12 positions. This can be grasped in a perpendicular conformation between them in the optimized structure (Fig. 6). [25] Upon photo-excitation, 8a-8d emit blue light. The emission spectra of $8 \mathrm{a}-8 \mathrm{~d}$ are seen nearly as mirror image to their absorption spectra, respectively, with small Stokes shifts $(9-13 \mathrm{~nm})$. The broadening band observed in that of $8 \mathrm{c}$ may be accounted by existence of vibrational sublevels due to rotation of the methoxy groups on the aryl groups. The emission quantum yields of $8 \mathrm{a}-8 \mathrm{~d}$ were found high up to 0.97 (Table 2), while the emission quantum yield of 7, 12-diphenylbenzo [ $k$ ] fluoranthene, which dose not have a dicarboximide moiety, is 0.48 . [26] It is worthy to note that introduction of the dicarboximide moiety on this $\pi$-system has brought about a great advance in their emission efficiency. Further studies on cycloaddition of 4 for synthesis of $\pi$-extended arene-dicarboximides and their application to electronic devices are in progress.

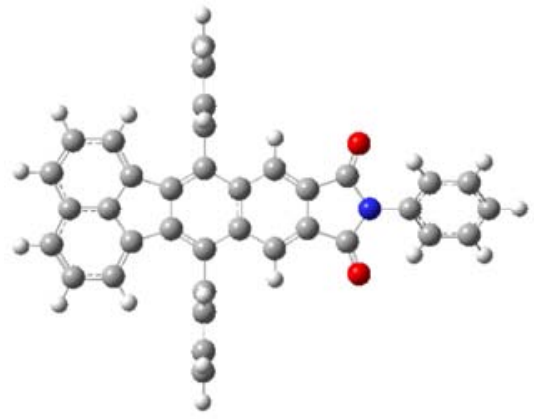

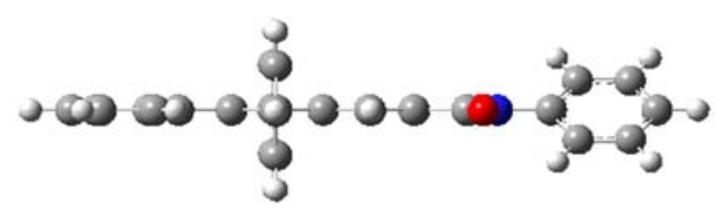

Figure 6. An optimized structure of 8 a. Caron and hydrogen atoms are shown in gray, oxygen atoms in red, and nitrogen atoms in blue. Top view (left) and side view (right).

\section{Experimental}

\subsection{General Remarks}

Melting points were measured on a Yanaco MP-3 and are uncorrected. IR spectra were recorded on a JASCO FT/IR-4100 spectrometer. UV-vis spectra were recorded on a Shimadzu UV-2550 spectrometer. Emission spectra were recorded on a Shimadzu RF5300-PC spectrometer. Emission quantum yields were obtained by calculations based on the absolute value of anthracene ( $\Phi=0.27$ in ethanol). [27-28 ${ }^{1} \mathrm{H}$ and ${ }^{13} \mathrm{C}$-NMR spectra were recorded on JEOL $\lambda 400$ and ECA500 spectrometers. Chemical shift values of tetramethylsilane ( $\delta=0 \mathrm{ppm}$ ) for ${ }^{1} \mathrm{H}-\mathrm{NMR}$ spectra and $\mathrm{CDCl}_{3}$ $(\delta=77.0 \mathrm{ppm})$ for ${ }^{13} \mathrm{C}$-NMR spectra were used as internal standard. Mass spectra were measured on a JMS-700 mass spectrometer. Column chromatography was performed with Silica gel 60N from Kanto Chem. Dioxane, dimethylsulfoxide (DMSO), and tetrahydrofuran (THF) were purchased from Kanto Chem. and were distilled over $\mathrm{CaH}_{2}$. Chloroform, dichloromethane (DCM), 1, 2-dichloroethane (DCE), and toluene were purchased also from Kanto Chem. and were distilled over $\mathrm{P}_{2} \mathrm{O}_{5}$. N-Phenylmaleimide, bis(diphenylphosphino)-1, 1'-binaphthyl (BINAP), triethylamine, tri- $n$-butylphosphine, tri- $n$-octylphosphine, and triflic acid were purchased from Tokyo Chemical Industry, Inc. Oxalyl chloride and $\mathrm{LiAlH}_{4}$ were purchased from Wako Chem. Pd (dppf) $\mathrm{Cl}_{2} \cdot \mathrm{CH}_{2} \mathrm{Cl}_{2}$ and cesium carbonate were purchased from Aldrich-Sigma Co. Diester 9 was prepared according to a procedure reported by Wang et al. [29] 


\subsection{Synthesis of Dimethyl 2, 5-bis-}

(4-Bromophenyl )Furan-3, 4-Dicarboxylate (9)

To a solution of 4-bromobenzoylchloride (11.0 g. 50.0 $\mathrm{mmol})$ in $50 \mathrm{~mL}$ of THF was added $4.32 \mathrm{~g}$ (3.00 mmol) of dimethyl maleate, followed by $11.7 \mathrm{~g}(58.0 \mathrm{mmol})$ of tri- $n$-butylphosphine and $10.5 \mathrm{~mL}(75.0 \mathrm{mmol})$ of triethylamine. This mixture was stirred at room temperature under nitrogen atmosphere for $20 \mathrm{~h}$. The resulted dark brown reaction mixture was poured into water and was extracted with chloroform $(50 \mathrm{ml} \times 3)$. The combined organic layer was washed with $1 \mathrm{M} \mathrm{HCl}$ solution, a saturated $\mathrm{NaHCO}_{3}$ aqueous solution, and brine. After drying over $\mathrm{Na}_{2} \mathrm{SO}_{4}$, the solvent was evaporated. The residual solids were recrystallized from chloroform to give $6.28 \mathrm{~g}(54 \%$ yield) of 9 as colorless microcrystals. M.p. $=163-164^{\circ} \mathrm{C}$. ${ }^{1} \mathrm{H}$ NMR $\left(400 \mathrm{MHz}, \mathrm{CDCl}_{3}\right) \delta=3.81(\mathrm{~s}, 6 \mathrm{H}), 7.52(\mathrm{dt}, J=$ 9.0, 2.2 Hz, 4H), $7.66(\mathrm{dt}, J=9.0,2.2 \mathrm{~Hz}, 4 \mathrm{H}) \mathrm{ppm} ;{ }^{13} \mathrm{C}$ NMR $\left(100 \mathrm{MHz}, \mathrm{CDCl}_{3}\right) \delta=163.8,152.6,131.9,128.9$, $127.5,124.2$, 115.8, $52.6 \mathrm{ppm}$; IR (KBr) $v=1719 \mathrm{vs}, 1487 \mathrm{~s}$, $1101 \mathrm{~s}, 992 \mathrm{~s}, 825 \mathrm{vs} \mathrm{cm}^{-1}$; UV-Vis $\left(\mathrm{CHCl}_{3}\right) \lambda_{\max }(\log \varepsilon)=310$ $(\log \varepsilon=4.40) \mathrm{nm} ; \mathrm{MS}(\mathrm{EI}) m / z(\%)=496\left(\mathrm{M}^{+}, 51\right), 494\left(\mathrm{M}^{+}\right.$, 100), 492 ( $\left.\mathrm{M}^{+}, 51\right), 465$ (12), 463 (24), 461 (12), 185 (10), 183 (10). HRMS calcd for $\mathrm{C}_{20} \mathrm{H}_{14}{ }^{79} \mathrm{Br}_{2} \mathrm{O}_{5}\left(\mathrm{M}^{+}\right)$491.9208, found 491.9217.

\subsection{Synthesis of Dimethyl 2, 5-bis (Biphenyl-4-yl) Furan-3, 4-Dicarboxylate (10)}

A mixture of $2.53 \mathrm{~g}(5.14 \mathrm{mmol})$ of $9,1.63 \mathrm{~g}(13.4 \mathrm{mmol})$ of phenylboronic acid, $178 \mathrm{mg}(0.28 \mathrm{mmol})$ of BINAP, and $203 \mathrm{mg}(0.249 \mathrm{mmol})$ of $\mathrm{Pd}(\mathrm{dppf}) \mathrm{Cl}_{2} \cdot \mathrm{CH}_{2} \mathrm{Cl}_{2}$ in $75 \mathrm{~mL}$ of toluene was refluxed on an oil bath under argon atmosphere for $3 \mathrm{~h}$. The resulted reaction mixture was poured into water and was extracted with chloroform $(50 \mathrm{~mL} \times 3)$. The combined organic layer was washed with a saturated $\mathrm{NaHCO}_{3}$ solution and brine, and was dried over $\mathrm{Na}_{2} \mathrm{SO}_{4}$. The solvent was removed and the residue was purified by $\mathrm{SiO}_{2}$ chromatography $(\mathrm{AcOEt} / \mathrm{Hexane}=3 / 7)$ to give $1.93 \mathrm{~g}(77 \%$ yield) of 10 as colorless solids. M.p. $=132-133^{\circ} \mathrm{C}$. ${ }^{1} \mathrm{H}$ NMR $\left(400 \mathrm{MHz}, \mathrm{CDCl}_{3}\right) \delta=3.92(\mathrm{~s}, 6 \mathrm{H}), 7.39(\mathrm{tt}, \mathrm{J}=7.4,1.5 \mathrm{~Hz}$, 2H), $7.47(\mathrm{tm}, \mathrm{J}=7.4 \mathrm{~Hz}, 4 \mathrm{H}), 7.65(\mathrm{dm}, \mathrm{J}=8.1 \mathrm{~Hz}, 4 \mathrm{H}$,), $7.70(\mathrm{dt}, \mathrm{J}=8.1,2.0 \mathrm{~Hz}, 4 \mathrm{H}),, 7.97(\mathrm{dt}, \mathrm{J}=8.1,2.0 \mathrm{~Hz}, 4 \mathrm{H})$ ppm; ${ }^{13} \mathrm{C}$ NMR $\left(100 \mathrm{MHz}, \mathrm{CDCl}_{3}\right) \delta=164.3,153.3,142.3$, $140.2,128.9,127.81,127.76,127.6,127.2,127.1,115.4$, $52.5 \mathrm{ppm}$; IR (KBr) $v=1728 \mathrm{vs}, 1486 \mathrm{~s}, 1100 \mathrm{~s}, 767 \mathrm{~s}, 727 \mathrm{~s}$, $694 \mathrm{~s}, 666 \mathrm{~s} \mathrm{~cm}^{-1}$; UV-Vis $\left(\mathrm{CHCl}_{3}\right) \lambda_{\max }=248(\log \varepsilon=4.23)$, 293sh (4.40), 330 (4.54) nm; MS (EI) m/z (\%) = $488\left(\mathrm{M}^{+}\right.$, 100), 457 (6), 245 (4), 244 (10), 181 (11), 153 (4), 152 (5). HRMS calcd for $\mathrm{C}_{32} \mathrm{H}_{24} \mathrm{O}_{5}\left(\mathrm{M}^{+}\right)$488.1624, found 488.1621 .

\subsection{Synthesis of 2, 5-bis (Biphenyl-4-yl) Furan-3, 4- Dicarbaldehyde (11)}

A solution of $850 \mathrm{mg}(1.74 \mathrm{mmol})$ of 10 in $10 \mathrm{~mL}$ of THF was added slowly to a suspension of $160 \mathrm{mg}$ of $\mathrm{LiAlH}_{4}(4.21$ $\mathrm{mmol}$ ) in $30 \mathrm{~mL}$ of $\mathrm{THF}$ at $0^{\circ} \mathrm{C}$. After being stirred at room temperature for $3 \mathrm{~h}$, the reaction mixture was carefully quenched by ethanol/water. The resulted mixture was passed through a Celite pad and was washed well with ether. The filtrate was dried over $\mathrm{MgSO}_{4}$ and the solvent was evaporated to give the crude solids. Recrystallization from ethanol/diethyl ether provided $291 \mathrm{mg}$ (40\% yield) of 2, 5-bis (biphenyl-4-yl)-3, 4-bis (hydroxymethyl)furan as colorless microcrystals. M.p. $>200^{\circ} \mathrm{C}$ (dec.). ${ }^{1} \mathrm{H}$ NMR $(400 \mathrm{MHz}$, DMSO-d $\left._{6}\right) \delta=4.62(\mathrm{~s}, 2 \mathrm{H}), 7.42(\mathrm{t}, \mathrm{J}=7.5 \mathrm{~Hz}, 2 \mathrm{H}), 7.51(\mathrm{t}$, $\mathrm{J}=7.5 \mathrm{~Hz}, 4 \mathrm{H}), 7.75(\mathrm{~d}, \mathrm{~J}=8.1 \mathrm{~Hz}, 4 \mathrm{H}), 7.83(\mathrm{~d}, \mathrm{~J}=8.1 \mathrm{~Hz}$, $4 \mathrm{H}), 7.94(\mathrm{~d}, \mathrm{~J}=8.1 \mathrm{~Hz}, 4 \mathrm{H}) \mathrm{ppm} ;{ }^{13} \mathrm{C} \mathrm{NMR}(100 \mathrm{MHz}$, $\left.\mathrm{CDCl}_{3}\right) \delta=149.0,139.5,139.3,129.3,129.0,127.6,127.1$, 126.6, 126.4, 123.8, 53.0 ppm; IR (KBr) $v=3384 \mathrm{~m}, 3330 \mathrm{~m}$, $1485 \mathrm{vs}, 1446 \mathrm{~s}, 1432 \mathrm{~s}, 1013 \mathrm{vs}, 996 \mathrm{~s}, 984 \mathrm{~s}, 848 \mathrm{~s}, 768 \mathrm{vs}, 755 \mathrm{~s}$, $692 \mathrm{~s} \mathrm{~cm}^{-1}$; MS (EI) m/z (\%) = $432\left(\mathrm{M}^{+}, 100\right), 430(18), 416$ (13), 414 (25), 181 (14), 152 (10). HRMS calcd for $\mathrm{C}_{32} \mathrm{H}_{24} \mathrm{O}_{5}$ $\left(\mathrm{M}^{+}\right)$432.1725, found 432.1726 .

A solution of dimethylsulfoxide $(0.5 \mathrm{~mL})$ in $10 \mathrm{~mL}$ of DCM was added dropwise to a solution of oxalyl chloride $(0.25 \mathrm{~mL}, 53.1 \mathrm{mmol})$ in $5 \mathrm{~mL}$ of $\mathrm{DCM}$ at $-80^{\circ} \mathrm{C}$, followed by addition of a solution of $363 \mathrm{mg}(0.840 \mathrm{mmol})$ of 2 , 5-bis (biphenyl-4yl)-3, 4-bis (hydroxymethyl)furan in 2 $\mathrm{mL}$ of DMSO and $5 \mathrm{~mL}$ of DCM, and then triethylamine $(2.0 \mathrm{~mL})$. After being stirred at the same temperature for 2 $\mathrm{h}$, the resulted reaction mixture was poured into water (30 $\mathrm{mL})$ and was extracted with DCM $(20 \mathrm{~mL} \times 3)$. The combined organic layer was washed with brine and dried over $\mathrm{NaSO}_{4}$. The solvent was removed and the residual solids were purified by recrystallization from hexane/chloroform to give $334 \mathrm{mg}$ (90\% yield) of 11 as colorless needles. M.p. $=180-182^{\circ} \mathrm{C} .{ }^{1} \mathrm{H}$ NMR $(400 \mathrm{MHz}$, $\left.\mathrm{CDCl}_{3}\right) \delta=7.42(\mathrm{tt}, \mathrm{J}=7.6,1.5 \mathrm{~Hz}, 2 \mathrm{H}), 7.50(\mathrm{tm}, \mathrm{J}=7.6$ $\mathrm{Hz}, 4 \mathrm{H}), 7.67(\mathrm{dm}, \mathrm{J}=7.6 \mathrm{~Hz}, 4 \mathrm{H}), 7.78(\mathrm{dm}, \mathrm{J}=7.6 \mathrm{~Hz}$, $4 \mathrm{H}), 8.09(\mathrm{dm}, \mathrm{J}=7.6 \mathrm{~Hz}, 4 \mathrm{H}), 10.51(\mathrm{~s}, 2 \mathrm{H}) \mathrm{ppm} ;{ }^{13} \mathrm{C}$ NMR $\left(100 \mathrm{MHz}, \mathrm{CDCl}_{3}\right) \delta=186.9,159.2,143.8,139.8$, 129.02, 129.00, 128.2, 127.5, 127.2, 126.7, 121.5 ppm; IR $(\mathrm{KBr}) \mathrm{v}=1687 \mathrm{vs}, 1660 \mathrm{vs}, 871 \mathrm{~s}, 847 \mathrm{~s}, 768 \mathrm{vs}, 733 \mathrm{~s}, 695 \mathrm{~s}$ $\mathrm{cm}^{-1}$; UV-Vis $\left(\mathrm{CHCl}_{3}\right) \lambda_{\max }=261(\log \varepsilon=4.53), 343(4.60)$ $\mathrm{nm} ; \mathrm{MS}(\mathrm{EI}) \mathrm{m} / \mathrm{z}(\%)=428\left(\mathrm{M}^{+}, 100\right), 401$ (11), $400(36)$, 181 (23), 153 (10), 152 (15). HRMS calcd for $\mathrm{C}_{30} \mathrm{H}_{20} \mathrm{O}_{3}$ $\left(\mathrm{M}^{+}\right)$428.1412, found 428.1417.

\subsection{Synthesis of 1, 3-bis (Biphenyl-4-yl)-N-Phenylisobenzo- Furan-5, 6-Dicarboximide (4d)}

A solution of $11 \quad(98.0 \quad \mathrm{mg}, \quad 0.23 \quad \mathrm{mmol})$, $N$-phenylmaleimide $\quad(78.0 \quad \mathrm{mg}, \quad 1.10 \quad \mathrm{mmol}), \quad$ and tri- $n$-octylphosphine $(4.0 \mathrm{~mL})$ in $3 \mathrm{~mL}$ of dioxane was refluxed on an oil bath under argon atmosphere for $3 \mathrm{~h}$. The orange solids formed were collected and washed well with hexane to give $89 \mathrm{mg}(68 \%$ yield $)$ of 4 d. M.p. $>300^{\circ} \mathrm{C}$. ${ }^{1} \mathrm{HNMR}\left(400 \mathrm{MHz}, \mathrm{CD}_{2} \mathrm{Cl}_{2}\right) \delta=7.41-7.56(\mathrm{~m}, 11 \mathrm{H}), 7.73(\mathrm{~d}$, $J=7.1 \mathrm{~Hz}, 4 \mathrm{H}), 7.85(\mathrm{~d}, J=8.6 \mathrm{~Hz}, 4 \mathrm{H}), 8.16(\mathrm{~d}, J=8.6 \mathrm{~Hz}$, $4 \mathrm{H}), 8.59$ (s, 2H) ppm; IR (KBr) $v=1758 \mathrm{vs}, 1707 \mathrm{vs}, 1482 \mathrm{vs}$, $1366 \mathrm{~s}, 1341 \mathrm{vs}, 1210 \mathrm{~s}, 1143 \mathrm{~s}, 1116 \mathrm{~s}, 1104 \mathrm{~s}, 848 \mathrm{~s}, 768 \mathrm{vs}$, $752 \mathrm{~s}, 728 \mathrm{~s}, 698 \mathrm{~s}, 612 \mathrm{~s} \mathrm{~cm}^{-1}$; UV $\left(\mathrm{CHCl}_{3}\right) \lambda_{\max }=253(\log \varepsilon=$ 4.69), 300 (4.33), 339 (4.18), 438sh (3.89), 475 (3.91) nm; MS (FAB) $m / z(\%)=568\left(\mathrm{M}^{+}, 100\right)$. HRMS (FAB) calcd for $\mathrm{C}_{40} \mathrm{H}_{25} \mathrm{NO}_{3}\left(\mathrm{M}^{+}\right)$568.1907, found 568.1908. [30] 


\subsection{General Procedure for Synthesis of 7, 12-Diaryl- N-Phenylbenzo/k]Fluoranthene-9, 10-Dicarboximides 8}

A solution of $4(1.00 \mathrm{mmol})$ and $7(6.00 \mathrm{mmol})$ in $10 \mathrm{~mL}$ of toluene was placed in a sealed tube under argon atmosphere and was heated on an oil bath until the isobenzofuran was consumed completely $(8-21 \mathrm{~h})$. Then, the solvent was removed and the residue was chromatographed through $\mathrm{SiO}_{2}$ to remove acenaphthylene. This crude adduct was dissolved in a solution of 10 equiv. of trilflic acid in 5 $\mathrm{mL}$ of DCE. After being heated at $65^{\circ} \mathrm{C}$ for $1-4 \mathrm{~h}$, the resulted reaction mixture was poured into water and was extracted with chloroform $(20 \mathrm{~mL} \times 3)$. The combined organic layer was washed with a saturated $\mathrm{NaHCO}_{3}$ solution and brine, and was dried over $\mathrm{Na}_{2} \mathrm{SO}_{4}$. The solvent was removed and the residue was purified by $\mathrm{SiO}_{2}$ chromatography to give the title compound. Yields are shown in Table 1.

8a: Orange powder, m.p. $>300^{\circ} \mathrm{C} .{ }^{1} \mathrm{H}$ NMR $(500 \mathrm{MHz}$, $\left.\mathrm{CDCl}_{3}\right) \delta=6.66(\mathrm{~d}, J=7.1 \mathrm{~Hz}, 2 \mathrm{H}), 7.38(\mathrm{t}, J=8.0 \mathrm{~Hz}, 2 \mathrm{H})$, $7.40-7.44(\mathrm{~m}, 3 \mathrm{H}), 7.50(\mathrm{tm}, J=7.7 \mathrm{~Hz}, 2 \mathrm{H}), 7.57(\mathrm{dm}, J=$ $7.5,1.8 \mathrm{~Hz}, 4 \mathrm{H}), 7.71(\mathrm{~m}, 6 \mathrm{H}), 7.80(\mathrm{~d}, J=8.1 \mathrm{~Hz}, 2 \mathrm{H}), 8.28$ (s, 2H) ppm; ${ }^{13} \mathrm{C} \mathrm{NMR}\left(126 \mathrm{MHz}, \mathrm{CDCl}_{3}\right) \delta=167.2,138.1$, $137.5,136.9,135.6,135.45,135.44,132.0,130.0,129.8$, $129.7,129.1,128.8,128.13,128.12,127.2,126.8,126.7$, 124.1, $123.6 \mathrm{ppm}$; IR $(\mathrm{KBr}) v=1769 \mathrm{~s}, 1719 \mathrm{vs} \mathrm{cm} \mathrm{cm}^{-1}$; UV $\left(\mathrm{CHCl}_{3}\right) \lambda_{\max }=257(\log \varepsilon=4.45), 284$ (4.60), 295 (4.71), 314 (4.66), 327 (4.84), 360 (4.06), 385 (3.84), 408 (4.27), 434 (4.49) nm; MS $m / z(\%)=549\left(\mathrm{M}^{+}, 100\right), 505(6), 429$ (11), 400 (11), 275 (8), 199 (5). HRMS calcd for $\mathrm{C}_{40} \mathrm{H}_{23} \mathrm{NO}_{2}\left(\mathrm{M}^{+}\right)$ 549.1729, found 549.1721.

8b: Orange powder, m.p. $>300^{\circ} \mathrm{C} .{ }^{1} \mathrm{H}$ NMR $(500 \mathrm{MHz}$, $\left.\mathrm{CDCl}_{3}\right) \delta=2.62(\mathrm{~s}, 6 \mathrm{H}), 7.39(\mathrm{t}, J=7.2 \mathrm{~Hz}, 2 \mathrm{H}), 6.75(\mathrm{~d}, J=$ $7.2 \mathrm{~Hz}, 2 \mathrm{H}), 7.43(\mathrm{~m}, 7 \mathrm{H}), 7.50(\mathrm{~m}, 6 \mathrm{H}), 7.79(\mathrm{~d}, J=8.0 \mathrm{~Hz}$, 2H), 8.29 (s, 2H) ppm; $\left.{ }^{13} \mathrm{C} \mathrm{NMR} \mathrm{(126} \mathrm{MHz,} \mathrm{CDCl}_{3}\right) \delta=$ $167.3,138.5,138.2,137.0,135.69,135.66,135.60,134.4$, $132.1,130.37,130.36,130.0,129.7,129.1,128.1,127.1$, 126.74, 126.71, 124.2, 123.6, $21.6 \mathrm{ppm}$; IR (KBr) $v=1766 \mathrm{~s}$, $1718 \mathrm{vs} \mathrm{cm}{ }^{-1}$; UV $\left(\mathrm{CHCl}_{3}\right) \lambda_{\max }=256(\log \varepsilon=4.41), 284 \mathrm{sh}$ (4.57), 294 (4.66), 314 (4.62), 327 (4.79), 356sh (4.03), 387 (3.79), 409 (4.21), 435 (4.43) nm; MS $m / z(\%)=577\left(\mathrm{M}^{+}\right.$, 100), 457 (5), 430 (5), 289 (7). HRMS calcd for $\mathrm{C}_{42} \mathrm{H}_{27} \mathrm{NO}_{2}$ $\left(\mathrm{M}^{+}\right)$577.2042, found 577.2032.

8c: Orange powder, m.p. $>300^{\circ} \mathrm{C} .{ }^{1} \mathrm{H}$ NMR $(500 \mathrm{MHz}$, $\left.\mathrm{CDCl}_{3}\right) \delta=4.03(\mathrm{~s}, 6 \mathrm{H}), 6.79(\mathrm{~d}, J=6.6 \mathrm{~Hz}, 2 \mathrm{H}), 7.24(\mathrm{dm}, J$ $=8.7 \mathrm{~Hz}, 4 \mathrm{H}), 7.38-7.44(\mathrm{~m}, 5 \mathrm{H}), 7.47(\mathrm{dm}, J=8.7 \mathrm{~Hz}, 4 \mathrm{H})$, $7.50(\mathrm{tm}, J=8.0 \mathrm{~Hz}, 2 \mathrm{H}), 7.80(\mathrm{~d}, J=8.0 \mathrm{~Hz}, 2 \mathrm{H}), 8.31$ (s, 2H) ppm; ${ }^{13} \mathrm{C}$ NMR $\left(126 \mathrm{MHz}, \mathrm{CDCl}_{3}\right) \delta=167.3,159.9$, $138.4,136.6,135.9,135.66,135.64,132.0,131.0,130.0$, $129.5,129.0,128.13,128.10,127.1,126.77,126.73,124.1$, $123.6,115.1,55.5 \mathrm{ppm}$; IR $(\mathrm{KBr}) v=1765 \mathrm{~s}, 1717 \mathrm{vs} \mathrm{cm}^{-1}$; $\mathrm{UV}\left(\mathrm{CHCl}_{3}\right) \lambda_{\max }=256(\log \varepsilon=4.43), 282$ (4.59), 293 (4.70), 316 (4.64), 327 (4.79), 360 (4.03), 386 (3.79), 409 (4.18), $435(4.40) \mathrm{nm} ; \mathrm{MS} m / z(\%)=609\left(\mathrm{M}^{+}, 100\right)$. HRMS calcd for $\mathrm{C}_{42} \mathrm{H}_{27} \mathrm{NO}_{4}\left(\mathrm{M}^{+}\right) 609.1940$, found 609.1944.

$8 \mathrm{~d}$ : Orange powder, m.p. $>300^{\circ} \mathrm{C} .{ }^{1} \mathrm{H}$ NMR $(400 \mathrm{MHz}$, $\mathrm{CDCl}_{3}$ at $\left.80^{\circ} \mathrm{C}\right) \delta=6.86(\mathrm{~d}, J=7.7 \mathrm{~Hz}, 2 \mathrm{H}), 7.34-7.48(\mathrm{~m}$,
9H), 7.54 (t, $J=7.7 \mathrm{~Hz}, 4 \mathrm{H}), 7.65(\mathrm{~d}, J=7.7 \mathrm{~Hz}, 4 \mathrm{H}), 7.78$ $(\mathrm{d}, J=7.7 \mathrm{~Hz}, 2 \mathrm{H}), 7.83(\mathrm{~d}, J=7.7 \mathrm{~Hz}, 4 \mathrm{H}), 7.95(\mathrm{~d}, J=7.7$ $\mathrm{Hz}, 4 \mathrm{H}), 8.35$ (s, 2H) ppm; ${ }^{13} \mathrm{C} \mathrm{NMR}\left(100 \mathrm{MHz}, \mathrm{CDCl}_{3}\right) \delta=$ 167.1, 142.0, 140.8, 138.4, 136.8, 136.7, 136.0, 135.8, 135.7, $132.6,130.54,130.45,129.1,129.0,128.4,128.2,128.0$, 127.8, 127.4, 127.3, 126.7, 124.0, 123.8 ppm; IR (KBr) $v=$ $1765 \mathrm{vs}, 1720 \mathrm{vs} \mathrm{cm}^{-1}$; UV $\left(\mathrm{CHCl}_{3}\right) \lambda_{\max }=263(\log \varepsilon=4.84)$, 282sh (4.77), 291 (4.81), 315sh (4.70), 329 (4.84), 363sh (4.10), 385 (3.87), 410 (4.25), 436 (4.45) nm; MS $m / z(\%)=$ $702\left(\mathrm{M}^{+}, 100\right)$. HRMS calcd for $\mathrm{C}_{52} \mathrm{H}_{31} \mathrm{NO}_{2}\left(\mathrm{M}^{+}\right)$702.2428, found 702.2440.

\section{Conclusion}

We have demonstrated that the novel title compounds, 7 , 12-diaryl- $N$-phenylbenzo $[k]$ fluoranthene-9, 10-dicarboximides (8a-d), could be synthesized from 1, 3-diaryl- $N$-phenylisobenzofuran-5, 6-dicarboximides $4 \mathrm{a}-\mathrm{d}$ in two steps by the Diels-Alder reaction with acenaphthylene (7) and subsequent dehydration with triflic acid. The long wavelength absorptions of 8a-d were observed similarly, suggesting that the aryl groups at the 7 and 12 positions do not make any contribution for extension of $\pi$-conjugation with the benzo[k]fluoranthene moiety. The fact can be rationalized by their perpendicular conformation between the aryl groups and the arene moiety. These dicarboximides $8 \mathrm{a}-\mathrm{d}$ showed emission under photo-excitation and their emission quantum yields were found very high.

\section{Acknowledgements}

A financial support (H26 Kenkyu-Keihi) from the Faculty of Science in Shinshu University (for M. O.) is greatly acknowledged.

\section{References}

[1] Y.-Y. Li, H.-Y. Lu, M. Li, X.-J. Li, and C.-F. Chen, "Dihydroindeno [2, 1-c]fluorene-based imide dyes: Synthesis, structures, photophysical and electrochemical properties", $J$. Org. Chem. 2014, 79, 2139-2147.

[2] X. Zhan, A. Facchetti, S. Barlow, T. J. Marks, M. A. Ratner, M. R. Wasielewski, and S. R. Marder, "Rylene and related diimides for organic electronics", Adv. Mater. 2011, 23, 268284.

[3] D. Xia, T. Marszalek, M. Li, X. Guo, M. Baumgarten, W. Pisula, and K. Müllen, "Solution-processable n-type organic semiconductors based on angular-shaped 1-(12H-dibenzofluoren-12-ylidene) malononitrilediimide", Org. Lett. 2015, 17, 3074-3077.

[4] B. Yao, X. Ye, J. Zhang, and X. Wan, "Electrochromism of a fused acceptor-donor-acceptor triad covering entire UV-vis and near-infrared regions", Org. Lett. 2014, 16, 5378-5381.

[5] C. Yuan, S. Saito, C. Camacho, S. Irle, I. Hisaki, and S. Yamaguchi, "A $\pi$-conjugated system with flexibility and rigidity that shows environment-dependent RGB luminescence", J. Am. Chem. Soc. 2013, 135, 8842-8845. 
[6] T. V. Pho, F. M. Toma, M. L. Chabinyc, and F. Wudl, "Self-assembling decacyclene triimides prepared through a regioselective hextuple Friedel-Crafts carbamylation", Angew. Chem. Int. Ed. 2013, 52, 1446-1451.

[7] S. Seifert, K. Shoyama, D. Schmidt, and F. Würthner, "An electron-poor $\mathrm{C}_{64}$ nanographene by palladium-catalyzed cascade $\mathrm{C}-\mathrm{C}$ bond formation: One-pot synthesis and single-crystal structure analysis", Angew. Chem. Int. Ed. 2016, $55,6390-6395$.

[8] Y. Zhong, B. Kumar, S. Oh, M. T. Trinh, Y. Wu, K. Elbert, P. Li, X. Zhu, S. Xiao, F. Ng, M. L. Steigerwald, and C. Nuckolls, "Helical ribbons for molecular electronics", J. Am. Chem. Soc. 2014, 136, 8122-8130.

[9] P. Nandhikonda and M. D. Heagy, "Dual fluorescent N-aryl-2, 3-naphthalimides: Applications in ratiometric DNA detection and white organic light-emitting devices”, Org. Lett. 2010, 12, 4796-4799.

[10] P. Nandhikonda and M. D. Heagy, "An abiotic fluorescent probe for cardiac troponin I", J. Am. Chem. Soc. 2011, 133, 14972-14974.

[11] P. Valat, V. Wintgens, J. Kossanyi, L. Biczók, A. Demeter, and T. Bérces, "Influence of geometry on the emitting properties of 2, 3-naphthalimides", J. Am. Chem. Soc. 1992, 114, 946-953.

[12] I. Saito, M. Takayama, and S. Kawanishi, "Photoactivatable DNA-cleaving amino acids: Highly sequence-selective DNA photocleavage by novel L-lysine derivatives", J. Am. Chem. Soc. 1995, 117, 5590-5591.

[13] I. Saito, M. Takayama, H. Sugiyama, K. Nakatani, A. Tsuchida, and M. Yamamoto, "Photoinduced DNA cleavage via electron transfer: Demonstration that guanine residues located 5' to guanine are the most electron-donating sites", J. Am. Chem. Soc. 1995, 117, 6406-6407.

[14] S. Li, L. Zhou, Z. Song, F. Bao, K. Kanno, and T. Takahashi, "Effect of substituents at 1, 4-positions of polycyclic aromatic compounds and preparation of 2, 3-difunctionalized pentacenes and naphthacenes", Heterocycles 2007, 73, 519536.

[15] V. Nair and K. G. Abhilash, "Engaging Morita-Baylis-Hillman reaction for the generation of isobenzofuran and the consequent entry into highly substituted aromatic systems", Synthesis 2005, 1967-1970.

[16] Y. Nishina, T. Kida, and T. Ureshino, "Facile Sc $(\mathrm{OTf})_{3}$-catalyzed generation and successive aromatization of isobenzofuran from $o$-dicarbonylbenzenes", Org. Lett. 2011, 13, 3960-3963.

[17] T. Iwanaga, R. Tanaka, and S. Toyota, "Introduction of an arylethynyl group onto an anthracene bisimide core for molecular design of new $\pi$-conjugated compounds", Chem. Lett. 2014, 43, 105-107.
[18] M. Oda, H. Shimosasa, Y. Kumai, A. Ohta, and R. Miyatake, "An improved synthesis of arenedicarboximides by phosphine-assisted annulation of arene-1, 2-dicarbaldehyde with N-Substituted maleimide", Modern Chem. 2014, 2, 2935 .

[19] H. Shimosasa, R. Miyatake, N. Kobayashi, and M. Oda "Synthesis and emission behavior of 1, 3-diarylisobenzofuran-5, 6-dicarboximides and their transformation into naphthalene-2, 3: 6, 7-bis (dicarboximide)s", Modern Chem. 2016, 4, 16-23.

[20] N. Kobayashi, S. Yamamoto, H. Shimosasa, M. Oda, and R. Miyatake, "Convenient synthesis of benzo $[b]$ thiophene-5, 6-dicarboximide derivatives and their photophysical properties", Modern Chem. 2016, 4, 45-51.

[21] T. Yanagisawa, N. Kabayashi, H. Shimosasa, Y. Kumai, R. Miytake, and M. Oda, "Synthesis and fluorescence property of, 2, 3-naphthalimide derivatives bearing phenyl substituents on the naphthalene skeleton", Dyes Pigments 2017, 136, 859-864.

[22] M. J. Haddadin, B. J. Agha, and R. F. Tabri, "Syntheses of some furans and naphtho $[2,3-c]$ derivatives of furan, pyrrole, and thiophene", J. Org. Chem. 1979, 44, 494-497.

[23] N. C. Thanh, M. Ikai, T. Kajioka, H. Fujikawa, Y. Taga, Y. Zhang, S. Ogawa, H. Shimada, Y. Miyahara, S. Kuroda, and M. Oda, "Synthesis of $N, N, N$ ', N'-tetrasubstituted 1, 3-bis (4-aminophenyl)azulenes and their application to a hole-injecting material in organic electroluminescent devices", Tetrahedron 2006, 62, 11227-11239.

[24] A. J. Mancuso and D. Swern, "Activated dimethyl sulfoxide: Useful reagents for synthesis", Synthesis 1981, 165-185.

[25] The structures were optimized at the B3LYP/6-31G (d) level of theory. DFT calculations were carried out by with the Gaussian 03 program, Revision D.01 program, Gaussian, Inc.: Pittsburgh, PA, 2003.

[26] Y.-H. Kung, Y.-S. Cheng, C.-C. Tai, W.-S. Liu, C.-C. Shin, C.-C. Ma, Y.-C. Tsai, T.-C. Wu, M.-Y. Kuo, and Y.-T, Wu, "Synthesis, structures, and physical properties of benzo [k]fluoranthene-based linear acenes", Chem. Eur. J. 2010, 16, 5909-5919.

[27] W. R. Dawson and M. W. Windsor, "Fluorescence yields of aromatic compounds", J. Phys. Chem. 1968, 72, 3251-3260.

[28] W. H. Melhuish, "Quantum efficiencies of fluorescence organic substances: Effect of solvent and concentration of the fluorescent solute", J. Phys. Chem. 1961, 65, 229-235.

[29] J. Wang, R. Zhou, Z.-R. He, and Z. He, "Phosphane-mediated domino synthesis of tetrasubstituted furans from simple terminal activated olefins", Eur. J. Org. Chem. 2012, 60336041 .

[30] Because of low solubility of this compound in deuterated solvents, its satisfactory ${ }^{13} \mathrm{C}$ NMR spectrum was not obtained. 